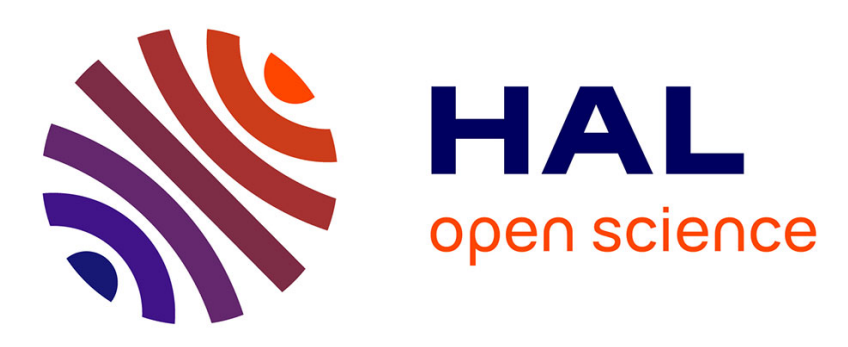

\title{
Environmental monitoring by surface sampling for cytotoxics: a review
}

Marie Petit, Christophe Curti, Manon Roche, Marc Montana, Charleric

Bornet, Patrice Vanelle

\section{To cite this version:}

Marie Petit, Christophe Curti, Manon Roche, Marc Montana, Charleric Bornet, et al.. Environmental monitoring by surface sampling for cytotoxics: a review. Environmental Monitoring and Assessment, 2017, 189 (2), pp.52. 10.1007/s10661-016-5762-9 . hal-01433551

\section{HAL Id: hal-01433551 \\ https://hal.science/hal-01433551}

Submitted on 17 Jan 2017

HAL is a multi-disciplinary open access archive for the deposit and dissemination of scientific research documents, whether they are published or not. The documents may come from teaching and research institutions in France or abroad, or from public or private research centers.
L'archive ouverte pluridisciplinaire HAL, est destinée au dépôt et à la diffusion de documents scientifiques de niveau recherche, publiés ou non, émanant des établissements d'enseignement et de recherche français ou étrangers, des laboratoires publics ou privés. 


\section{Environmental monitoring by surface sampling for cytotoxics:}

\section{a review}

${ }^{1}$ Assistance Publique - Hôpitaux de Marseille (AP-HM), Service Central de la Qualité et de l'Information Pharmaceutiques (SCQIP), Hôpital de la Conception, 147 Boulevard Baille, 13005 Marseille, France.

${ }^{2}$ Aix-Marseille Université, CNRS, ICR, UMR 7273, Laboratoire de Pharmaco-Chimie Radicalaire, Faculté de Pharmacie, 27 Boulevard Jean Moulin - CS30064, 13385 Marseille cedex 05, France.

${ }^{3}$ Assistance Publique - Hôpitaux de Marseille (AP-HM), Service Central des Opérations Pharmaceutiques (SCOP), Administration centrale, rue Brochier, 13005 Marseille, France.

${ }^{4}$ Assistance Publique - Hôpitaux de Marseille (AP-HM), Oncopharma, Hôpital Nord, Chemin des Bourrely. 13915. Marseille cedex 20, France

${ }^{5}$ Assistance Publique - Hôpitaux de Marseille (AP-HM), Pharmacie Usage Intérieur Hôpital de la Conception, Hôpital de la Conception, 147 Boulevard Baille, 13005 Marseille, France.

Keywords:cytotoxic drugs, surface sampling, chromatography, hospital.

\section{Corresponding author:}

*Corresponding author: Manon ROCHE, Assistance Publique - Hôpitaux de Marseille (AP-HM), Service Central des Opérations Pharmaceutiques (SCOP); Aix Marseille Université, ICR, UMR 7273 CNRS, Marseille, France. E-mail: manon.roche@univ-amu.fr. tel: +33-(0)4 918355 25; fax: +33(0)4 91794677 
30 Object:Environmental monitoring is usually conductedby surface sampling to detect and quantify the presence of cytotoxic drugs after their reconstitution and administration. This technique revealsthe origins of residual contamination and is an important component in order toprotect healthcare workers from the potential risk of occupational exposure. The aim of this work is to compare various techniques and results of surface sampling

34 for cytotoxics.

Materials and methods:For each technique, sample processing methods and their analysis werecompared from literature data. Sampling is often performed by the wiping technique. After treatment, various single or multicompound technicalanalyses are used, in particular liquid or gas chromatography involving different detection methods: ultraviolet, mass spectrometry, plasma torch, voltammetry. Some methods are validated to ensure reliability.

40 Results: Despite published guidelinesand the use of isolator technology for the preparation of cytotoxic drugs, workplace contamination persists,leading tochemotherapeutic agents' exposure of healthcare workers. Efforts need to be maintained with particular emphasis on harmonization and on determining alert level for cytotoxic contamination.

\section{Introduction}

In recent decades, cancer survival has improved due to advances in cancer treatment by chemotherapy.Unfortunately, treated patients suffer from significant side effects, because the cytotoxic activity of anticancer drugs also extends tonormal cells. Healthcare workers'occupational exposure to cytotoxic drugs has been recognized as a potential health hazard since the 1970s (Ng and Jaffe 1970; Donner 1978). Hospital personnel involved in the preparation or administration of cytotoxic agents is exposed to a wide variety of antineoplastic substances. The precautionary principle requires that exposure should be as low as possible (Turci and Minoia 2006), and minimizingexposureappears to be a real challenge. Numerouspublished guidelines exist, like the Good Manufacturing Practices in France (ANSM 2007) or those of several other countries (OSHA 1999; Schierl et al. 2009; Randolph 2012; Easty et al. 2015). Several good occupational hygiene practices were also published worldwide, as World Health Organization regional office for European Union countries (WHO Europe 2002). Following the US National Institute for Occupational Safety and Health (NIOSH) publication, many healthcare organizations (American Society of Health-System Pharmacists 2006; International Society of 
Oncology Pharmacy Practitioners 2007; USP <797> 2004; Working Committee on the Safe Handling of Hazardous Drugs 2008) revised their guidelines, policies and procedures in order to enhance safety for care workers (National Institute for Occupational Safety and Health 2004). However, despite compliance with safety directives contamination can occur. improve working conditions through effective cleaning or protection of cytostatic drugs handlerespecially. Even though hospital personnelmay be exposed to antineoplastic agents by inhalation or by inadvertent ingestion (hand-to-mouth contamination for example), direct skin contact appears to be the primary path of exposure.

To ensure accurate risk assessment, a monitoring strategy is recommended, withthe following conditions (Turci et al. 2003): sources of contamination in working areas must be identified. The efficacy of personal protective equipment and biological safety cabinets (BSC) must be verified. Contamination of other areas adjacent to the area of preparation and administration rooms must be monitored and controlled. Information on work activities should be compiled to allow different periods to be compared.

Rapid, reliable and validated analytical methods are needed to ensure safe handling of these dangerous drugs by reducing healthcare workersexposure to the lowest possible level. While the literature covers numerous analytical methods of environmental monitoring, few authors in the past carried out a formalized validation on their assay. Most of them were reviewed in 2003 (Turciet al. 2003). Only more recent studies include validation procedures using quality controls (QCs). Several techniques were developed for the detection of a single compound, but assay techniques have since tended towards simultaneous detection of several compounds (multicompound technology). Since workers are usually exposed to a large number of drugs, studies focusedon the most toxic (Group 1 IARC) and the most frequently prescribed drugs.

Biological and environmental monitorings are essential to identify the potential paths of exposure and to improveprocedures. Moreover, generalization and standardization of environmental monitoring allows theestablishment of guidance values, useful tool for occupational safety. Considering the current scientific knowledge limitation on toxicity of chronic exposure to nanomolar quantities of cytotoxic drugs,these guidance values are actually based on comparison of results of environmental monitoring. This risk assessment requires specific standardized sampling techniques and analytical methods. In this review, a critical overview of the main methods of environmental monitoring available in the literature is presented. In addition, the procedures that have been validated as ensuring reliability are highlighted. The results of the largest surveys in hospital departments are also cited with a view to improving both monitoring strategies and working conditions. 


\section{Cytotoxic drugs covered by environmental sampling}

91 Cytotoxic chemotherapeutic agents can be divided into several classes (OSHA 1999; Turci et al. 2003).

Alkylating agents forming covalent bonds with DNA and RNA and leading to the formation of adducts.

93 They include nitrogen mustards (such as cyclophosphamide (CP), and ifosfamide (IF)), derivatives of platinum (such as cisplatin $(\mathrm{Pt})$ ) and nitrosoureas (such as the carmustine).

Antimetabolites are nucleotide structural analogs and are incorporated into cellular components, inhibiting nucleic acids synthesisand leading to cell death. They include antifolates (such as methotrexate (MTX)), pyrimidine analogues (such as cytarabine (Cyt), gemcitabine (Gem) and 5-fluorouracil (5FU)) and purine analogs (such as fludarabine).

Topoisomerase inhibitors are designed to be insertedbetween the pairs of bases of DNA and to disrupt the synthesis and / or function of nucleic acids. Topoisomerase I inhibitors are derived from camptothecins (such as topotecan(Top) and irinotecan (Iri)) and topoisomerase II inhibitorscontain anthracyclines (such as doxorubicin (Dox) andepirubicin (Epi)) and epipodophyllotoxin derivatives (such as etoposide (Eto)).

Finally, anti-proliferative agents disrupting mitotic spindle include taxanes (such as paclitaxel(Pac)and docetaxel (Doc)) and vinca-alkaloids (such as vincristine (VCR)).

Several cytostatic drugs are classified as carcinogenic to humans (Group 1) by the International Agency for Research on Cancer (IARC)(International Agency for Research on Cancer 2016). This classification (Table

107 1) is based on epidemiological studies showing the development of secondary tumors in cancer patients treated with these drugs and primary tumors in patients treated with medications for other purposes. Several cytotoxic drugs are classified by IARC in group 2A and 2B (probably and possibly carcinogenic to humans, respectively).

110 Antimetabolites and mitotic spindle agents are not classifiable as carcinogenic to humans (Group 3).

111 Nevertheless, they remain mutagenic and teratogenic.

112 Table 1: Classification of anticancer drugs according to IARC monographs

\begin{tabular}{ccc}
\hline Cytotoxicchemotherapeutic agents & Groups & Group definition \\
CP, etoposide & Group 1 & Carcinogenic to humans \\
Bleomycin, dacarbazine & Group 2A & Probablycarcinogenic to humans \\
\hline IF, 5FU, MTX, vincristine, vinblastine & Group 2B & Possibly carcinogenic to humans \\
Pac, Doc, Top, Iri, Epi, Cyt, Gem & Group 3 & Actually not classified in IARC monographs
\end{tabular}

113 CP: cyclophosphamide; Pt: cisplatin; Dox: doxorubicin; IF: ifosfamide; 5FU: 5-fluorouracil; MTX: methotrexate; Pac: paclitaxel; Doc:

114 docetaxel; Top: topotecan; Iri: irinotecan; Epi: epirubicin; Cyt: cytarabine; Gem: gemcitabine. 
A wide variety of these drugs were analyzed for environmental monitoring (National Institute for

116 Occupational Safety and Health 2014), primarilycyclophosphamide (CP), ifosfamide (IF), methotrexate (MTX),

117 5-fluorouracil (5FU), cisplatin(Pt), paclitaxel (Pac), vinca alkaloids and anthracyclines. These substances are

118 among the most frequently used and the most important from a toxicological point of view. In addition, they are 119 commercially available as analytical standard products.

120 Any choice of marker cytotoxic drugs should be based on a thorough knowledge of hospital activities 121 and specialties. For example, hospitals carrying out the Heated Intraperitoneal Perioperative Chemotherapy 122 Procedure (HIPEC) should evaluate environmental contamination for platinum derivatives(Konate et al. 2011).

\section{Environmental sampling dosing methods}

The range of drugs monitored depends on currently available analytical techniques. High performance via previously described multi-compound techniques. Inductively coupled plasma mass spectrometry (ICP-MS) or voltammetry can be used for environmental monitoring of platinum salts. High performance liquid 130 chromatography - UV detection (LC-UV) imposes a choice of marker cytotoxic drugs, such as CP (Siderov et 131 al. 2010) or 5FU(Tkaczuk et al. 2010; Lee et al. 2007). Gaz chromatography - mass spectrometry (GC/MS) was 132 also used for the environmental monitoring of CP, IF and 5FU (Sessink et al. 1992; Castiglia et al. 2008; Kosjek et al. 2013).

Wipe sampling method and extraction

In several investigations, wipe sampling was performed on different surfaces and objects. Thiswas the most

138 common practice to monitor residual contamination in reconstitution and care areas, administrative units, 139 equipment, and to test the effectiveness of decontamination techniques (Sottani et al. 2007). A variety of 140 materials, of sampling areas, of types of solution and volumes of desorption solution were addressed. Major wipe sampling and extraction methods are detailed in Table 2.

144 LC/MS/MS means that preconcentration is not always necessary (Sabatini et al. 2005). 
146 (LLE). SPE is often described as faster than LLE, but also more expensive and it does not always allow to 147 increase the Limit of Detection (LOD) and the Lowest Limit of Quantitation (LLQ) (Juhascik and Fenkins 2009).

151 Table 2: Sampling and extraction techniques for cytotoxic drugs environmental monitoring.

\begin{tabular}{|c|c|c|c|}
\hline Drug quantified (Reference) & Sampling technique & Extraction technique & Extraction yields \\
\hline Pac (Sottani et al. 2000) & Cotton / methanol & LLE (water pH 7.0/ethyl acetate) & $>90 \%$ \\
\hline 5FU (Gilles et al. 2009) & Filter paper $\left(\right.$ Whatman ${ }^{\circledR}$ ) & LLE (water/ethylacetate/isopropanol) & $71 \%$ \\
\hline 5FU (Micoli et al. 2001) & Cotton / acetate buffer ( $\mathrm{pH} 4.7)$ & SPE Isolute ${ }^{\circledR}$ ENV+ columns $(200 \mathrm{mg} / 6 \mathrm{~mL})$ & Mean $=94.1 \%$ \\
\hline 5FU (Kosjek et al. 2013) & $100 \mathrm{~mL}$ water samples & SPE Isolute ${ }^{\circledR}$ ENV+ columns $(500 \mathrm{mg} / 6 \mathrm{~mL})$ & $\begin{array}{l}\text { Wastewater }=53 \pm 28 \% \\
\text { Surface water }=93 \pm 2 \%\end{array}$ \\
\hline MTX (Turci et al. 2000) & Cotton & SPE Isolute ${ }^{\circledR} \mathrm{C} 18(500 \mathrm{mg} / 10 \mathrm{~mL})$ & Mean $=78.4 \%$ \\
\hline CP (Hedmer et al. 2004) & Nonwoven swab / NaOH $0.03 \mathrm{M}$ & LLE (water/ethyl acetate) & $>78 \%$ \\
\hline Pt (Brouwers et al. 2007) & $\begin{array}{l}\text { Kimtech }^{\circledR} \text { Science precision } \\
\text { wipes / water }\end{array}$ & $\begin{array}{l}\text { Ultrasonic desorption }(1 \% \mathrm{HCl}) \text { and } \\
\text { filtration }\end{array}$ & $50.4 \%$ to $81.4 \%$ \\
\hline 5FU, CP, MTX (Sabatini et & Kleenex $^{\circledR} /$ ammonium acetate & none & 5FU MTX: $\approx 78 \%$ \\
\hline al. 2005) & solution ( $\mathrm{pH} 6.9)$ & & CP: $100 \%$ \\
\hline 5FU, IF, CP (Castiglia et al. & TNT gauzes / NaOH $0.03 \mathrm{M}$ & Ultrasonicdesorption, & NR \\
\hline 2008) & & diatomaceousearth (elutiondiethylether) & \\
\hline $\mathrm{CP}, \mathrm{IF}, \mathrm{Pac}, \mathrm{Gem}$ (Sottani et & Ashless filter paper & OASIS $^{\circledR}$ HLB cartridges $(200 \mathrm{mg} / 6 \mathrm{~mL})$ & Gem: $62-81 \%$ \\
\hline al. 2007) & $\left(\right.$ Whatman $\left.{ }^{\circledR}\right)$ / water & SPE & $\begin{array}{l}\text { Pac: } 55-81 \% \\
\text { CP, IF: } 63-81 \%\end{array}$ \\
\hline CP, Cyt, Dox, Epi, Eto, Gem, & Blotting paper $\left(\right.$ Whatman $\left.^{\circledR}\right)$ & Ultrasonic desorption (water/formic acid) & From $20 \%$ (VCR) to $89 \%$ \\
\hline IF, Iri, MTX, VCR & & & (Cyt) on stainless steel \\
\hline (Nussbaumer et al. 2010) & & & surfaces. \\
\hline CP, Cyt, Dox, Epi, Eto, Gem, & Filter paper $\left(\right.$ Whatman $\left.{ }^{\circledR}\right)$ & Ultrasonic desorption (water/ACN/formic & From $45 \%$ (Eto) to $86 \%(\mathrm{CP})$ \\
\hline IF, Iri, MTX, VCR & & acid) and centrifugation & on stainless steel surfaces \\
\hline
\end{tabular}

152 CP: cyclophosphamide; Pt: cisplatin; Dox: doxorubicin; IF: ifosfamide; 5FU: 5-fluorouracil; MTX: methotrexate; Pac: paclitaxel; Doc:

153 docetaxel; Top: topotecan; Iri: irinotecan; Epi: epirubicin; Cyt: cytarabine; Gem: gemcitabine; VCR: vincristine; SPE: solid phase extraction;

154 LLE: liquid-liquid extraction.

156 When analyzed by LC-UV, 5FU always needs to be concentrated by LLE or SPE. 5FU is very difficult to extract

157 byreverse phase (RP)SPE because it is an extremely polar weak acid (Kosjek et al. 2013).5FU extraction yields 
were evaluated for several SPE columns, with highly varying recovery results, from $0.2 \%$ to more than

90\%.Isolute ${ }^{\circledR}$ ENV+ SPE appears to be the most suitable column,(Micoli et al. 2001; Kosjek et al. 160 2013)providing effective extraction regardless of both 5FU concentration and applied volume (Micoli et al. $1612001)$.

LC-UV sensitivity appears to be inadequate for environmental monitoring of CP without 163 preconcentration. A sufficiently sensitive method, for example with SPE as in biological sample 164 treatment(Baumann and Freiss 2001),needs to be developed.Currently, samples can be analyzed with either 165 LC/MS/MS or Gas chromatography - mass spectrometry (GC/MS). Six different types of wipe tissue were evaluated for their recovery potential: Easi-Tex Master ${ }^{\circledR}$ Plus, Care Facial ${ }^{\circledR}$ tissues, nonwoven swabs, sterile compresses, Kimcare ${ }^{\circledR}$ medical wipes and Swedish filter papers (Hedmer et al. 2004). Nonwoven swabs had the best and the highest CP absorption capacity. Size of sampling area was also evaluated $\left(100\right.$ or $\left.400 \mathrm{~cm}^{2}\right)$ and a large sample area was generally preferable.

SPE should be avoided for Pac because the vehicle formulation (Cremophor $\mathrm{EL}^{\circledR}$ ) can affect the effectiveness of the extraction technique. Instead of SPE, LLE with ethyl acetate can be used (Sottani et al. 2007).For MTX, however, SPE is necessary with LC-UV analysis and withLC/MS/MS for smaller areas, such as gloves. LLE is not recommended because of the low aqueous solubility of MTX (Turci et al. 2000).

For platinum environmental monitoring (Brouwers et al. 2007), wipe materials (Kimtech ${ }^{\circledR}$ wipes, Whatman ${ }^{\circledR}$ filters and Klinion ${ }^{\circledR}$ gauzes) were evaluated for platinum contamination and for their ability to release platinum from stainless steel surfaces. Wipe solvents (water, $1 \% \mathrm{HCl}, 80 \%$ ethanol) and desorption solvents (1\% $\mathrm{HNO}_{3}, 5 \% \mathrm{HNO}_{3}, 1 \% \mathrm{HCl}$ ) were also evaluated. Best experimental conditions were reported (Entry 7). demonstrated to be more than $20 \%$ according to surface type (for example, stainless steel hood work tray, linoleum flooring, laminated bench top) (Sottani et al. 2007). cytotoxicdrugs simultaneously. Initially, this elegant method involved wipe sampling with blotting paper 184 al. 2010). The major limitation of this method was the wide variation in percentagerecovered among the 10 cytotoxic drugs, from $18 \pm 12 \%$ (VCR) to $94 \pm 10 \%$ (Cyt). High standard deviations were also reported, for example $34 \pm 18 \%$ for Iri. Several modifications were consequently realized to improve this technique and 
solution, thereby increasing the hydrophobic substancesrecovery, and a centrifugation step was added. Then, several filter papers (Whatman ${ }^{\circledR}$, Ahlstrom ${ }^{\circledR}$, Texwipe $^{\circledR}$ ) were compared, and theWhatman ${ }^{\circledR}$ filter paper was best for environmental monitoring. Finally, recoveries were assessed on a wide variety of surfaces (stainless steel, polypropylene, polystyrol, glass, latex, computer mouse, paperboard) for each cytotoxic, enabling to determine a correction factor per compound and per surface.

193

LLQs and LODs of environmental analysis

GC/MS, LC-UV or LC/MS/MS are the most frequently analytical techniques used for cytotoxic analysis (Sottani et al. 2007). LLQ is often defined as the lowest concentration level with between-day relative error and precision less than or equal to $20 \%$ and LOD is the concentration giving signal intensity at least equal to three times the background value (Micoli et al. 2001). LLQ and LOD of several techniques are presented in Table 3. Moreover, these methods were validated with determination of linearity and accuracy in most of the cases. use $\mathrm{ng} / \mathrm{mL}$ (sample concentration) or $\mathrm{ng} / \mathrm{cm}^{2}$ (surface of the area sampled), or $\mathrm{ng}$ (per sample). Where possible, the units described by authors were harmonized here, in order to facilitate comparison. We believe that expressing LOD, LLQ and surface contamination results in $\mathrm{ng} / \mathrm{cm}^{2}$ should be standardized,facilitating comparison of results from different studies, this unit of measurement is also more readily comprehensible to clinicians.

217 Table 3: LLQs and LODs of analytical techniques for environmental monitoring 


\begin{tabular}{|c|c|c|c|c|c|c|c|c|}
\hline Reference & Analytes & Technique & $\begin{array}{l}\text { LOD } \\
(\mathrm{ng} / \mathrm{mL})\end{array}$ & $\begin{array}{l}\text { LLQ } \\
(\mathrm{ng} / \mathrm{mL})\end{array}$ & $\begin{array}{l}\text { LOD } \\
\left(\mathrm{ng} / \mathrm{cm}^{2}\right)\end{array}$ & $\begin{array}{l}\text { LLQ } \\
\left(\mathrm{ng} / \mathrm{cm}^{2}\right)\end{array}$ & $\begin{array}{l}\text { LOD } \\
\text { (ng/sample) }\end{array}$ & $\begin{array}{l}\text { LLQ } \\
\text { (ng/samp } \\
\text { le) }\end{array}$ \\
\hline Huizing et al. $1995^{\mathrm{p}}$ & $\mathrm{Pac}^{\mathrm{n}}$ & LC-UV & & $\begin{array}{l}\text { SPE: } 10 \\
\text { LLE: } 250\end{array}$ & . & & & \\
\hline Sotani et al. 2007 & $\mathrm{Pac}$ & LC/MS/MS & & & & & & 10 \\
\hline Sessink et al. $1992^{\circ}$ & MTX & LC-UV & 60 & & $0.4-1$ & & $3-6$ & \\
\hline Turci et al. 2000 & MTX & LC-UV & & & & & & 150 \\
\hline Turci et al. 2000 & MTX & LC/MS/MS & & & & & & 5 \\
\hline Micoli et al. 2001 & $5 \mathrm{FU}$ & LC-UV & & & & & 50 & 150 \\
\hline Gilles et al. 2009 & $5 \mathrm{FU}$ & LC-UV & 5 & 15 & & & & \\
\hline Sessink et al. $1992^{\circ}$ & $5 \mathrm{FU}$ & LC-UV & 7 & & $0.04-0.1$ & & $0.3-0.7$ & \\
\hline Kosjek et al. 2013 & $5 \mathrm{FU}$ & GC/MS/MS & $\begin{array}{l}0.16-0.48 \\
10^{-3}\end{array}$ & $0.54-1.610^{-3}$ & & & & \\
\hline Hedmer et al. 2004 & $\mathrm{CP}$ & LC/MS/MS & & & $0.0510^{-3}$ & & 0.02 & \\
\hline McDevitt et al. $1993^{\circ}$ & $\mathrm{CP}$ & LC-UV & & & $3-25$ & & & \\
\hline Sessink et al. $1992^{\circ}$ & $\mathrm{CP}$ & GC/MS & 0.1 & & $0.01-0.02$ & & $0.06-0.1$ & \\
\hline Minoia et al. $1998^{p}$ & $\mathrm{CP}, \mathrm{IF}$ & LC/MS/MS & & & 0.01 & & 20 & \\
\hline Castiglia et al. 2008 & $3^{\mathrm{a}, \mathrm{b}, \mathrm{d}}$ & $\begin{array}{l}\text { GC/MS/MS } \\
\text { LC-UV } \\
\text { a,d }\end{array}$ & & & $\begin{array}{l}0.12,{ }^{\mathrm{a}} \quad 0.6,^{\mathrm{d}} \\
4.4^{\mathrm{b}}\end{array}$ & $0.2,{ }^{\mathrm{a}} 1,{ }^{\mathrm{d}} 7.4^{\mathrm{b}}$ & & \\
\hline Sabatini et al. 2005 & $3^{\mathrm{a}, \mathrm{b}, \mathrm{c}}$ & $\mu \mathrm{LC} / \mathrm{MS} / \mathrm{MS}$ & $1.1^{\mathrm{a}, \mathrm{c}} 33.3^{\mathrm{b}}$ & & $\begin{array}{l}0.01^{\mathrm{a}, \mathrm{c}} \\
0.33^{\mathrm{b}}\end{array}$ & & & \\
\hline Sottani et al. 2007 & $4^{\mathrm{a}, \mathrm{d}, \mathrm{e}, \mathrm{f}}$ & $\mathrm{LC} / \mathrm{MS} / \mathrm{MS}$ & & & $\begin{array}{l}0.125^{\mathrm{e}, \mathrm{f}} \\
0.0625^{\mathrm{a}, \mathrm{d}}\end{array}$ & $\begin{array}{l}0.25^{\mathrm{e}, \mathrm{f}} \\
1.25^{\mathrm{a}, \mathrm{d}}\end{array}$ & $\begin{array}{l}12.5 \mathrm{e}, \mathrm{f} \\
6.25^{\mathrm{a}, \mathrm{d}}\end{array}$ & $\begin{array}{l}25^{\mathrm{e}, \mathrm{f}} \\
12.5^{\mathrm{a}, \mathrm{d}}\end{array}$ \\
\hline Connor et al. 2010 & $5^{\mathrm{a}, \mathrm{b}, \mathrm{d}, \mathrm{e}, \mathrm{g}}$ & LC/MS/MS & & & $\begin{array}{l}0.13,{ }^{\mathrm{g}} 0.1^{\mathrm{a}, \mathrm{d}} \\
0.07,,^{\mathrm{e}} 0.06^{\mathrm{b}}\end{array}$ & & & \\
\hline $\begin{array}{l}\text { Nussbaumer et al. } \\
2010\end{array}$ & $10^{\mathrm{a}, \mathrm{c}, \mathrm{d}, \mathrm{f}, \mathrm{g}, \mathrm{h}, \mathrm{i}, \mathrm{j}, \mathrm{k}, \mathrm{l}}$ & LC/MS/MS & $\leq 0.5$ & $0.25-2$ & & & & \\
\hline $\begin{array}{l}\text { Nussbaumer et al. } \\
2012\end{array}$ & $10^{\mathrm{a}, \mathrm{c}, \mathrm{d}, \mathrm{d}, \mathrm{f}, \mathrm{h}, \mathrm{h}, \mathrm{i}, \mathrm{j}, \mathrm{k}, \mathrm{l}}$ & LC/MS/MS & & & & 0.1 & & 10 \\
\hline Kiffmeyer et al. 2013 & $8^{\mathrm{a}, \mathrm{b}, \mathrm{c}, \mathrm{d}, \mathrm{e}, \mathrm{f}, \mathrm{l}, \mathrm{m}}$ & LC/MS/MS & $0.07-0.35$ & $0.1-1$ & & $\begin{array}{l}\left(3.7^{\mathrm{a}, \mathrm{c}, \mathrm{d}, \mathrm{l}}, 7.3^{\mathrm{f}},\right. \\
\left.11^{\mathrm{b}}, 18^{\mathrm{e}}, 37^{\mathrm{m}}\right) \\
10^{-3}\end{array}$ & & $\begin{array}{l}3.3^{\mathrm{a}, \mathrm{c}, \mathrm{d}, \mathrm{l}} \\
6.6-9.9^{\mathrm{b}, \mathrm{f}} \\
17-33^{\mathrm{e}, \mathrm{m}}\end{array}$ \\
\hline Schmaus et al. 2002 & Platinum & Voltammetry & & & $10^{-5}$ & & $510^{-3}$ & \\
\hline Ensslin et al. $1994^{\circ}$ & Platinum $^{\mathrm{n}}$ & Voltammetry & $1.810^{-3}$ & & & & & \\
\hline Brouwers et al. 2007 & Platinum & ICP-MS & & $0.510^{-3}$ & & $0.0510^{-3}$ & & $510^{-3}$ \\
\hline
\end{tabular}

$218{ }^{\mathrm{a}} \mathrm{CP},{ }^{\mathrm{b}} 5 \mathrm{FU},{ }^{\mathrm{c}} \mathrm{MTX},{ }^{\mathrm{d}} \mathrm{IF},{ }^{\mathrm{e}} \mathrm{Pac},{ }^{\mathrm{f}} \mathrm{Gem},{ }^{\mathrm{g}} \mathrm{Cyt},{ }^{\mathrm{h}} \mathrm{VCR},{ }^{\mathrm{i}} \mathrm{Dox},{ }^{\mathrm{j}} \mathrm{Epi},{ }^{\mathrm{k}} \mathrm{Iri},{ }^{\mathrm{l}} \mathrm{Eto},{ }^{\mathrm{m}}$ Doc ${ }^{\mathrm{n}}$ analysis on biological samples ${ }^{\mathrm{o}}$ Method validation was not

219 described in this reference ${ }^{\mathrm{p}}$ Method validation done on biological samples. 
CP: cyclophosphamide; Dox: doxorubicin; IF: ifosfamide; 5FU: 5-fluorouracil; MTX: methotrexate; Pac: paclitaxel; Doc: docetaxel; Top: topotecan; Iri: irinotecan; Epi: epirubicin; Cyt: cytarabine; Gem: gemcitabine; VCR: vincristine

When compared with LC/MS/MS, LC-UV analytical techniques for environmental monitoring suffer 224 from a lack of sensitivity, but also from a lower specificity. In particular for environmental samples,because of the presence of many agents on the working surface, LC/MS/MS remains the gold standard.

Laboratories equipped with an LC/MS/MS should use multi-compound methods for environmental monitoring(Nussbaumer et al. 2000; Nussbaumer et al. 2002; Connor et al. 2010; Kiffmeyer et al. 2013). If the investment appears too high, mono-compound analyses by LC-UV can be alternately worked out. As these methods are time-consuming and the LLQsare higher, the cytotoxic assessed must be chosen carefully.GC/MS and GC/MS/MS were mainly described for the monitoring of CP and IF (Sessink et al. 1992; Castiglia et al. 231 2008), involving a derivatization step using fluorinated anhydrides. GC/MS/MS can also be used for 5FU monitoring, after a derivatization step by silylation with MTBSTFA (N-methyl-N-[tert233 butyldimethylsilyl]trifluoroacetamide), described as the better reagent for 5FU(Kosjek et al. 2013). Currently, 234 there are no standardsfor environmental exposure to cytotoxics. USP $<797>$ recently stated that more than $2351 \mathrm{ng} / \mathrm{cm}^{2}$ of $\mathrm{CP}$ was found to cause human uptake. MEWIP, a large-scale investigation, led to a cytotoxic236 independent target value of $0.1 \mathrm{ng} / \mathrm{cm}^{2}$, based on the $90^{\text {th }}$ percentile of the results (Kiffmeyer et al. 2013). CP, MTX and 5FU were the main cytotoxic drugs chosen for environmental monitoring from the 1990s by LC-UV(Sessink et al. 1992), and currently by LC/MS/MS. MTX went from an LOD of $0.4 \mathrm{ng} / \mathrm{cm}^{2}$ to an LLQ of $3.710^{-3} \mathrm{ng} / \mathrm{cm}^{2}, 5 \mathrm{FU}$ from an LOD of $0.04 \mathrm{ng} / \mathrm{cm}^{2}$ to an LLQ of $1110^{-3} \mathrm{ng} / \mathrm{cm}^{2}$, and CP from an LOD of 3 $\mathrm{ng} / \mathrm{cm}^{2}$ toan LLQ of $3.710^{-3} \mathrm{ng} / \mathrm{cm}^{2}$ (Sessink et al. 1992; Kiffmeyer et al. 2013).In the absence of any consensus, 241 but when compared with the USP values for CP and the MEWIP project target values, the LODs of the methods using LC-UV for MTX and CP do not appear to be sufficient for environmental monitoring. However, the LOD of $5 \mathrm{FU}$ evaluated by LC-UV (from $0.04 \mathrm{ng} / \mathrm{cm}^{2}$ to $0.1 \mathrm{ng} / \mathrm{cm}^{2}$ ) may be low enough for effective monitoring. The

244 assessment of Pacenvironmental monitoring with LC/MS/MS methods alone was assessed (Sottani et al. 2007; 245 Sottani et al. 2000; Connor et al. 2010; Kiffmeyer et al. 2013), led to LLQs ranging from $18.10^{-3}$ to $125.10^{-3}$ $246 \mathrm{ng} / \mathrm{cm}^{2}$,depending on the protocol.Nevertheless,it should be possible to develop LC-UV Pac monitoring using 247 protocols described for biological samples, even though the detection limit will be higher (Huizing et al. 1995). 248 Platinum derivative environmental monitoring with both ICP-MS and voltammetrywas assessed, with similar 249 LODs and LLQs (Brouwers et al. 2007; Schmaus et al. 2002; Ensslin et al. 1994). As voltammetry appears to be 250 less expensive than ICP-MS, it should be the preferred platinum environmental monitoring method. 
252 cytotoxic surface contamination in near real time, appears very promising, with LODs ranging from 0.1 to 0.25

$253 \mathrm{ng} / \mathrm{cm}^{2}$ (Smith et al. 2015).

254

255 Applications and discussion

256

257 Several procedures for cytotoxic drug environmental evaluation were applied in preparation and

258 administrationunits. Results for selected cytotoxics are summarizedin Table 4.

259

260 Table 4:Environmental monitoring of selected cytotoxicsin preparation and administrationunits.

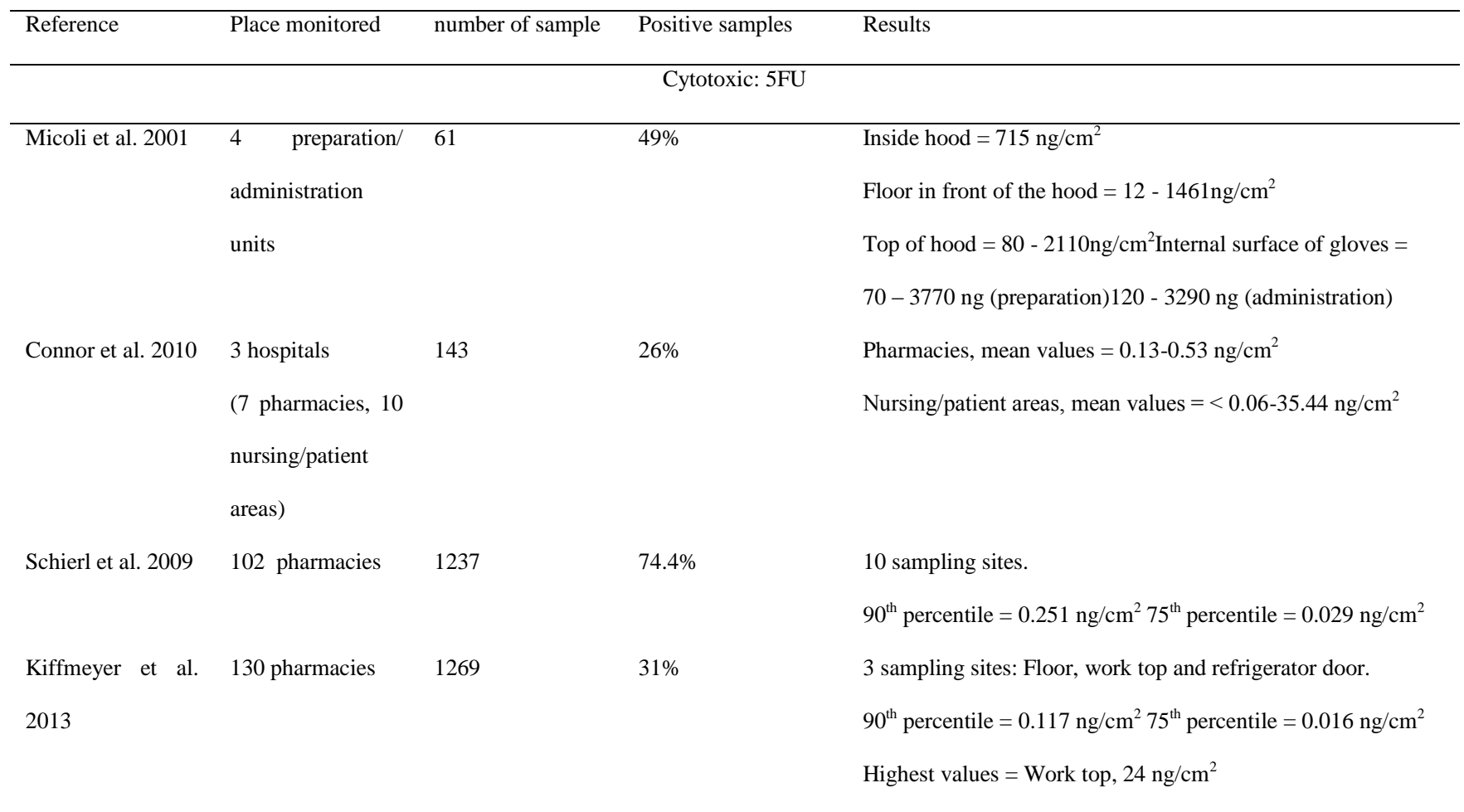

Cytotoxic: CP

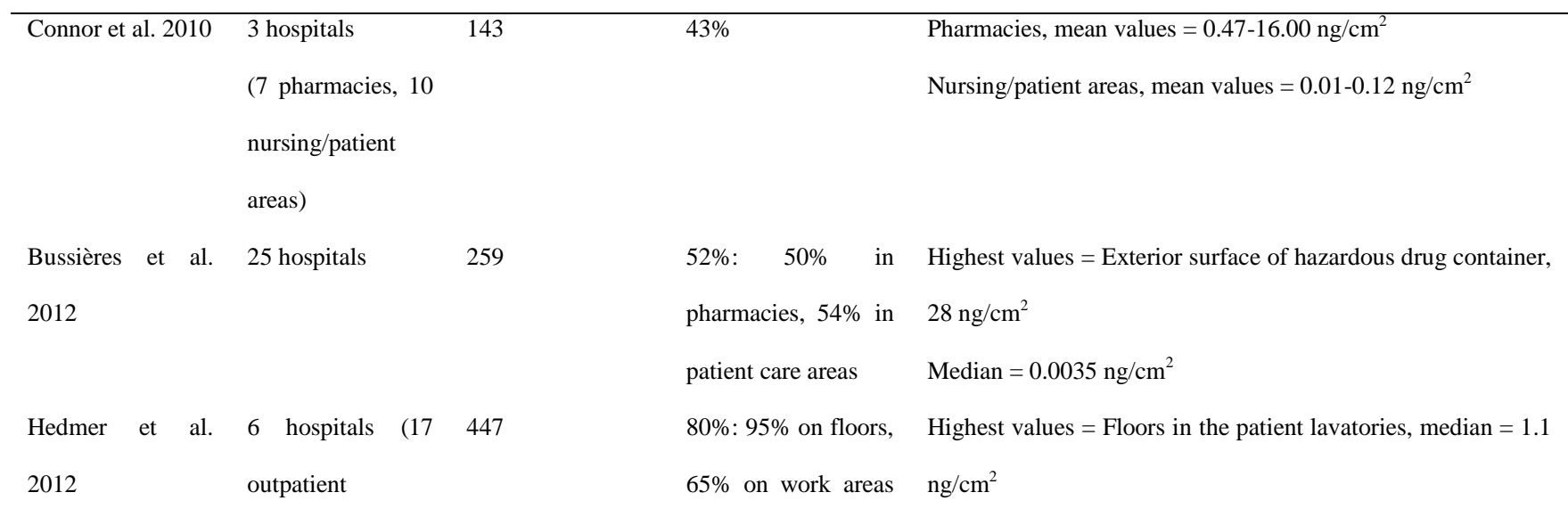


wards/wards)

Kiffmeyer et al. 130 pharmacies 2013
$53 \%$ on handles

$90^{\text {th }}$ percentile values calculated for different surfaces, ranging from $4.2 \mathrm{ng} / \mathrm{cm}^{2}$ (floors in the patient lavatory) to $6.10^{-5}$ $\mathrm{ng} / \mathrm{cm}^{2}$ (handles of transport box).

Median $=0.0033 \mathrm{ng} / \mathrm{cm}^{2}$

3 sampling sites: Floor, work top and refrigerator door.

$90^{\text {th }}$ percentile $=0.048 \mathrm{ng} / \mathrm{cm}^{2} 75^{\text {th }}$ percentile $=0.007 \mathrm{ng} / \mathrm{cm}^{2}$

Cytotoxic: IF

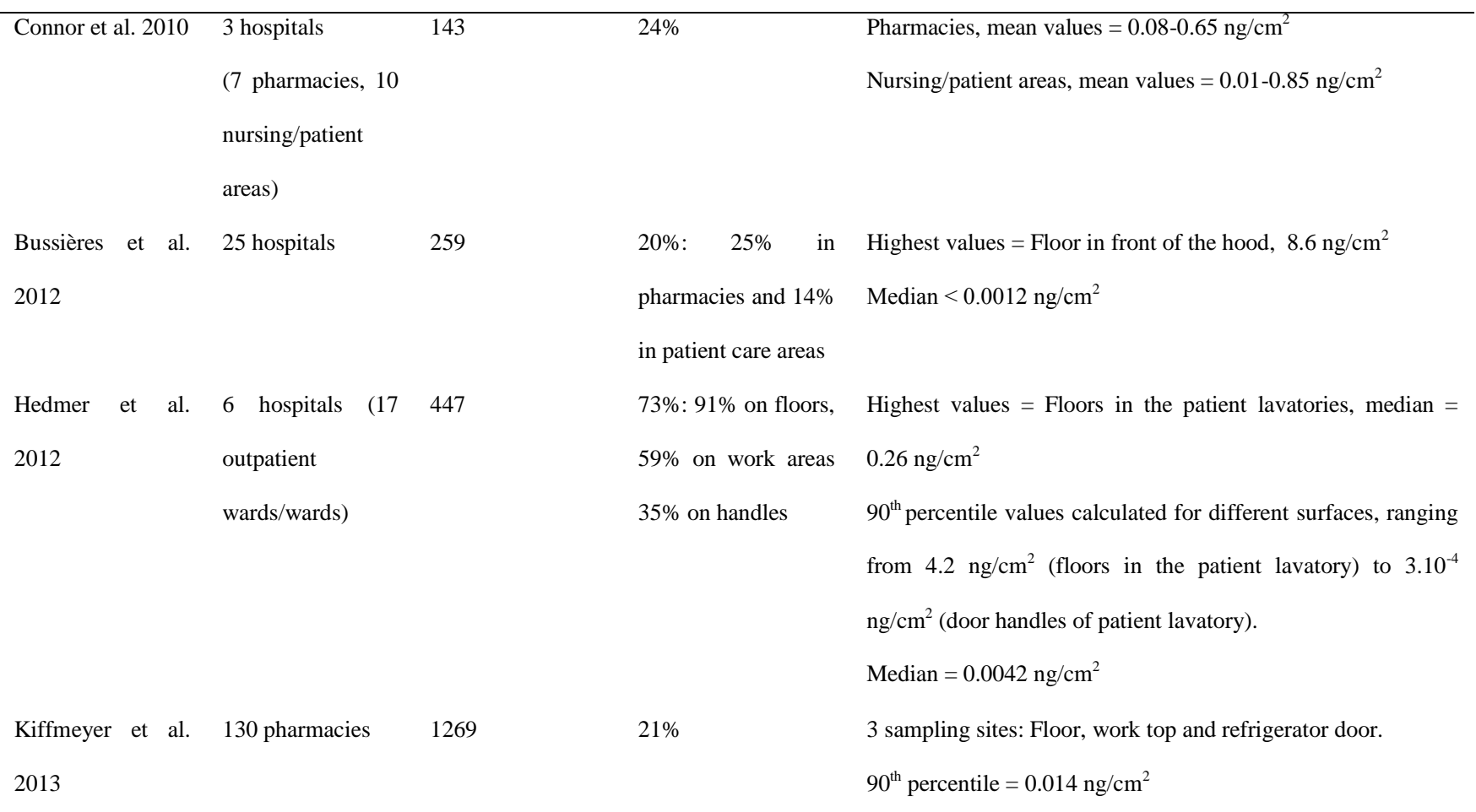

Cytotoxic: MTX

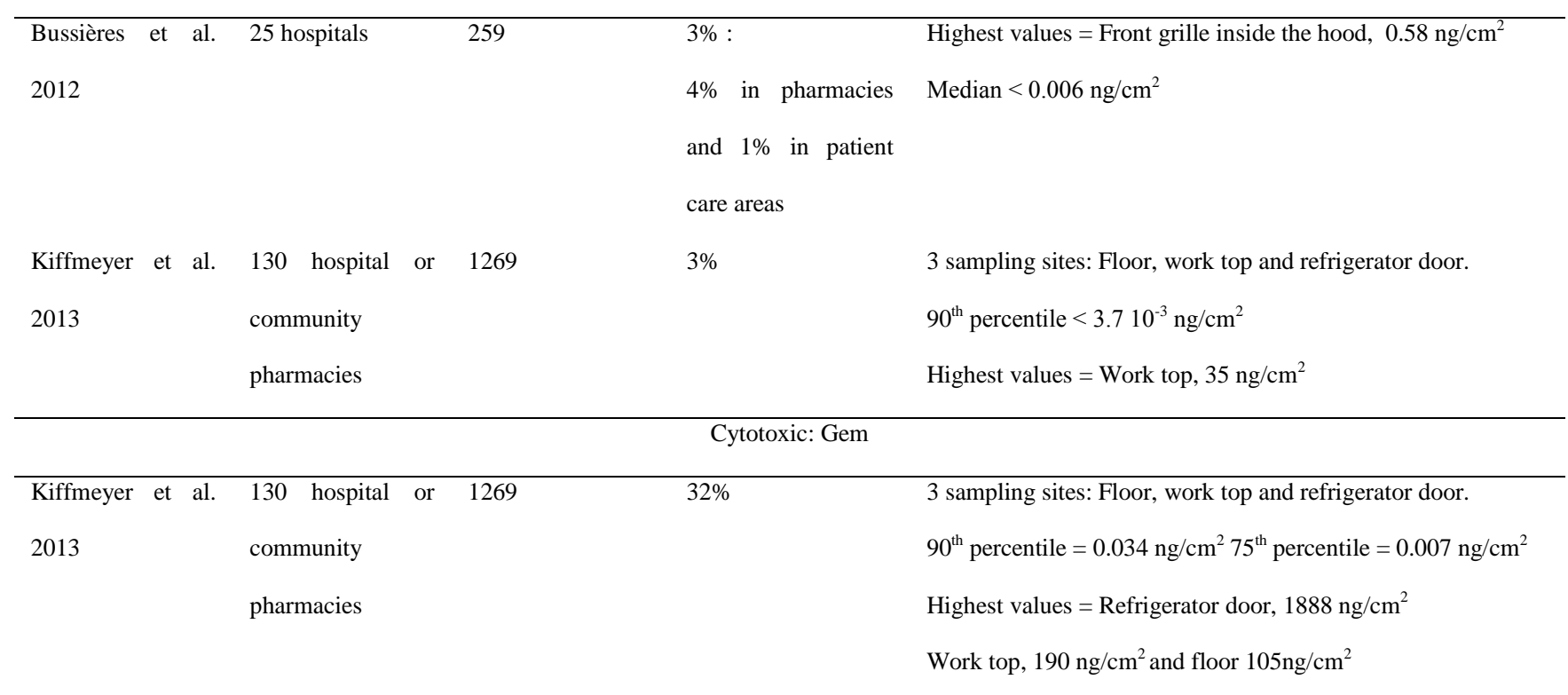

Cytotoxic: $\mathrm{Pt}$

\begin{tabular}{lllll}
\hline Schierl et al. 2009 & 102hospital & or 1008 & $99.2 \%$ & 10 sampling sites.
\end{tabular}


264 Naito et al. 2012; Nygren et al. 2002)described surface contamination ofmarketed cytotoxic drug vials, with a

265 possibility of cross-contamination by cytotoxic drugs. No Food and Drug Administration (FDA)requirements 266 exist regarding cleanliness of bottle external surfaces. However, contamination may be reduced by using a 267 decontamination device (Touzin et al. 2008) and protective sleeves (Schierl et al. 2010) during manufacturing. 268 Furthermore, cytotoxic drug contamination of marketed vials could be evaluated and taken into account in the 269 hospital tender procedure.

A clear improvement in protection for workers handling cytotoxics has been made in recent years.

271 Where simple laminar flow hoods (Mason et al. 2005) were used in the past, today, they often have been replaced by pressure isolators. In units where isolators are used, while contaminants were often found inside 273 isolators, only a few traces were found outside (Kopp et al. 2013; Crauste-Manciet et al. 2005). Isolators' 274 effectiveness mainly depends on operators' work practices, and contamination from the pass-through could be 275 reduced by surface decontamination. Several studies also demonstrated the efficacy of closed-system drug 276 transfer device (CSTDs) (Wick et al. 2003; Connor et al. 2002), which can reduce contamination by95\% 277 (Sessink et al. 2011). Robot assisted preparationswere also developed to reduce residual contamination from $27870 \%$ under classic preparation conditions to $15 \%$ with the Apoteca ${ }^{\circledR}$ chemo system (Schierl et al. 2016). 279 Similarly, the CytoCare ${ }^{\circledR}$ chemotherapy compounding robot allowed preparation of CP with low environmental 280 contamination levels and no measurable exposure of technicians (Sessink et al. 2015).

281 However, despite subsequentrecommendations and solutions to environmental monitoring, 282 contamination cannotcurrently be totally eliminatedandoccupational exposurescan occur. Adverse effects on 283 workers handling cytotoxic agents were describedsuch as hair loss, rash (Valanis et al. 1993; Krstey et al. 2003) 284 and delayed effects on reproduction (Stücker et al. 1993; Valanis et al. 1999; Fransman et al. 2007). Some 285 antineoplastic drugs are genotoxic (Rombaldi et al. 2009; Cavallo et al. 2005) and are known to cause or 286 suspected of causing cancerous pathologies (Connor 2006; International Agency for Research on Cancer 2016). 287 Therefore, several environmental monitoring studies involved biological assessment ofcytotoxic excretion in 288 healthcare-professionals (Turci et al. 2003; Pethran et al. 2003; Schreiber et al. 2003; Sottani et al. 2010). 289 Analysis of chromosomal effects on the DNA of workers exposed to cytotoxic drugs by fluorescent in situ 
hybridization (FISH) was conducted, seeking the"signature"lesions found in patients with myelodysplastic 291 syndrome (MDS) or acute myeloid leukemia (AML) (McDiarmid et al. 2014). A dose-related increase wasdetected, showing that significant biological exposure to genotoxic drugs occurs in oncology workplaces. Environmental monitoring of cytotoxic drugs should follow two main principles. In order to analyze the exposure of healthcare workers and the safety of the "preparation to administration" process, it is necessary to 295 realize a wide variety of sampling points, including surfaces and objects. On the other hand, to evaluate the impact of monitoring on contamination level,the number of sampling points should be standardized. et al. 2006; Kiffmeyer et al. 2013),but environmental monitoring can also be performed in care areas(Connor et al. 2010) or at every step of the cytotoxic drug circuit.For example, secondary exposure of family members to cytotoxic drugs via excreta of the treated cancer patient was recently described for CP. Levels of 0.03-7.34 $\mathrm{ng} / \mathrm{cm}^{2}$ were found in patients' home, and cytotoxic drugs werealso found in urine samples of family members (Yuki et al. 2013; Yuki et al. 2015). Exposure to cytotoxic drugs outside the hospital environment could also concern the pharmaceutical industry, universities, pharmacies, veterinary practices, laundry facilities and waste treatment(Meijster et al. 2006).For example, patients' bed sheets appeared to be contaminated with detectable levels of cytotoxics $\left(0.13-30.6 \mathrm{ng} / \mathrm{cm}^{2}\right)$ before the washing procedure in an industrial laundry facility(Fransman et al. 2007).

Several studies demonstrated the value of regular environmental monitoring. The MEWIP Project aimed to collect informations about the mechanisms and the release/propagation pathways of cytotoxic drugs(Kiffmeyer et al. 2013). To study the impact of monitoring, 130 pharmacies were randomized into two groups.Environmental monitoring in group A was regular throughout the study period, but occurred only at the

311 beginning and at the end of the project in group B. Using a validatedmulticompound technique(Tuerk et al. 312 2011),eight cytotoxics were quantified, a sample being considered positive if at least one of the drugs was 313 detected. Contamination levels were constantly decreasing in group Apharmacies, where, after the first report of 314 results, cleaning protocols, gloves, equipment modifications and more intensive training of cytotoxic drugs' 315 handlerwere implemented. Thus, it appears that repeated monitoring has a greater effect on level of 316 contamination than a single campaign.Another multicenter study was performed after publication of a prevention 317 guide recommending annual monitoring and the development of an environmental monitoring program(Bussières et al. 2012).Every hospital included had at least one sample with a positive result for at least 
one cytotoxic (CP, IF or MTX). Once again, periodic monitoring of surface contamination was shown to ensure updating of practices for better worker protection.

Current knowledge is too limited to set a no-health-effect levelfor cytotoxic drug exposure (Schierl et al. 2009), and a zero level of exposure is not likely to be achievable in workplaces(Kiffmeyer et al. 2013).However, as analytical techniques evolve, LLQs decrease and the number of positive samples increases, even though mean contamination levelshave beenreduced.In 2009 (Schierl et al. 2009) and 2013(Kiffmeyer et al. 2013),two large studies established from more than 1,200 wipe samplings and more than 100 hospitals or community pharmacies, a mean level of contamination by $5 \mathrm{FU}$ and other cytotoxic drugs. For $5 \mathrm{FU}$, although the number of positive samples varied from $31 \%\left(\mathrm{LLQ} 5 \mathrm{FU}=11 \mathrm{pg} \cdot \mathrm{cm}^{-2}\right)$ to $74.4 \%\left(\mathrm{LLQ} 5 \mathrm{FU}=0.75 \mathrm{pg} . \mathrm{cm}^{-2}\right)$, the $75^{\text {th }}$ and $90^{\text {th }}$ percentile from these studies were similar $\left(90^{\text {th }}\right.$ percentile $=0.117$ and $0.251 \mathrm{ng} / \mathrm{cm}^{2}, 75^{\text {th }}$ percentile $=0.016$ and $\left.0.029 \mathrm{ng} / \mathrm{cm}^{2}\right)$. The first study suggested technical guidance values based on the $50^{\text {th }}\left(5.10^{-3} \mathrm{ng} / \mathrm{cm}^{2}\right)$ and the $75^{\text {th }}$ percentile $\left(0.03 \mathrm{ng} / \mathrm{cm}^{2}\right)($ Schierl et al. 2009).The second study recommended less strict technical guidance values, based on the $90^{\text {th }}$ percentile $\left(0.1 \mathrm{ng} / \mathrm{cm}^{2}\right)$. This guidance value is the same for all 8 cytotoxic drugs tested in the study. This recommendation is based on two factors: the urgent need to improve the situation in workplaces with high levels of contamination, and the possibility that the $75^{\text {th }}$ percentile of most substances will fall below the LLQ. Furthermore, this technical guidance value of $0.1 \mathrm{ng} / \mathrm{cm}^{2}$, applied to CP, is tenfold lower than the USP $<797>$ value (a content higher than $1 \mathrm{ng} / \mathrm{cm}^{2}$ ofCP was found to cause human uptake). These guidance values were established for pharmacies, asthere are fewer studies conducted in hospital wards. From our knowledge, only one large study (Hedmer et al. 2012) conducted in 17 workplaces from 6 hospitals allowed

338 the authors to determine guidance values for hospital wards for CP and IF. In this study, the authors emphasized on the heterogeneity of contamination among the different categories of tested surfaces. The suggested guidance values were established from the $90^{\text {th }}$ percentile, for each sort of surface.

\section{Conclusion}

343 The reliability of detection techniques is constantly improving. Multi-compound analyses allow fast and 344 economical environmental monitoring. However, theconstant decrease in detection limits inevitably leads to anincrease in positive samples. Without toxicological studies establishing a correlation between exposure values

346 and health impact on healthcare workers, "as low as reasonably achievable" levels remain the gold standard. 
contamination evaluation, but also to evaluate technologies involved in the cytotoxic drug circuit.Recommended dosing techniques should be used routinely in every place where cytotoxic exposure is suspected. Good practice recommendations need to include environmental monitoring from the industrial process to the patient's home, with a special focus on hospital pharmacies and care areas. Real awareness has emerged inseveral countries regarding the overall management of cytotoxics, but international or at least national recommendations for environmental contamination monitoring are needed.

\section{References}

American Society of Health-System Pharmacists.(2006) ASHP guidelines on handling hazardous drugs.American Journal of Health-System Pharmacy, 63(12), 1172-1191.

ANSM: French National Agency of Medicine and Health Products Safety. (2007) Bonnes pratiques de preparation, chapitre 7: Préparations de médicaments contenant des substances dangereuses pour le personnel et l'environnement. Ressource document.http://ansm.sante.fr/var/ansm_site/storage/original/application/a5d6ae4b3d5fdee013ca463462b7b2 96.pdf Accessed 20 june 2016.[French]

Baumann, F.; Preiss, R. (2001) Cyclophosphamide and related anticancer drugs.Journal of chromatography.B, Biomedical sciences and applications, 764(1-2), 173-192.

Brouwers, E.E.;Huitema, A.D.; Bakker, E.N.;Douma, J.W.;Schimmel, K.J.; Van Weringh, G., et al. (2007) Monitoring of platinum surface contamination in seven Dutch hospital pharmacies using inductively coupled plasma mass spectrometry. International Archives of Occupational and Environmental Health, 80(8), 689699.

Bussières, J.F.;Tanguay, C.;Touzin, T. (2012) Environmental Contamination with Hazardous Drugs in Quebec Hospitals.Canadian Journal of Hospital Pharmacy, 65(6), 428-435.

Castiglia, L.;Miraglia, N.; Pieri, M.;Simonelli, A.;Basilicata, P.;Genovese, G., et al.(2008)Evaluation of occupational exposure to antiblastic drugs in an Italian hospital oncological department.Journal of Occupational Health, 50(1), 48-56.

Cavallo, D.;Ursini, C.L.;Perniconi, B.; Di Francesco, A.;Giglio, M.;Rubino, F.M., et al. (2005) Evaluation of genotoxic effects induced by exposure to antineoplastic drugs in lymphocytes and exfoliated buccal cells of oncology nurses and pharmacy employees.Mutation Research, 587(1-2), 45-51.

Connor, T.H.; Anderson, R.W.;Sessink, P.J.; Spivey, S.M. (2002) Effectiveness of a closed-system device in containing surface contamination with cyclophosphamide and ifosfamide in an i.v. admixture area. American Journal of Health-System Pharmacy, 59(1), 68-72.

Connor, T.H.;Sessink, P.J.; Harrison, B.R.; Pretty, J.R.; Peters, B.G.; Alfaro, R.M., et al. (2005) Surface contamination of chemotherapy drug vials and evaluation of new vial-cleaning techniques: results of three studies.American Journal of Health-System Pharmacy, 62(5), 475-484.

Connor, T.H. (2006) Hazardous anticancer drugs in health care: environmental exposure assessment. Annals of the New York Academy of Sciences, 1076, 615-623.

Connor, T.H.;DeBord, D.G.; Pretty, J.R.; Oliver, M.S.; Roth, T.S.; Lees, P.S., et al. (2010) Evaluation of Antineoplastic Drug Exposure of Health Care Workers at Three University-Based US Cancer Centers. Journal of Occupational and Environmental Medicine, 52(10), 1019-1027. 
Crauste-Manciet, S.;Sessink, P.J.; Ferrari, S.;Jomier, J.Y.; Brossard, D. (2005) Environmental contamination with cytotoxic drugs in healthcare using positive air pressure isolators. Annals of Occupational Hygiene, 49(7), 619-628.

Donner, A.L. (1978) Possible risk of working with antineoplastic drugs in horizontal laminar flow hoods. American journal of hospital pharmacy, 35(8), 900.

Easty, A.C.; Coakley, N.; Cheng, R.;Cividino, M.; Savage, P.; Tozer, R., et al. (2015) Safe handling of cytotoxics: guideline recommendations.Current Oncology, 22(1), e27-37.

Ensslin, A.S.;Pethran, A.;Schierl, R.;Fruhmann, G. (1994) Urinary platinum in hospital personnel occupationally exposed to platinum-containing antineoplastic drugs. International Archives of Occupational and Environmental Health, 65(5), 339-342.

Favier, B.; Gilles, L.;Ardiet, C.;Latour, J.F. (2003) External contamination of vials containing cytotoxic agents supplied by pharmaceutical manufacturers.Journal of Oncology Pharmacy Practice, 9(1), 15-20.

Fleury-Souverain, S.;Nussbaumer, S.;Mattiuzzo, M.;Bonnabry, P.(2014)Determination of the external contamination and cross-contamination by cytotoxic drugs on the surfaces of vials available on the Swiss market.Journal of Oncology Pharmacy Practice, 20(2), 100-111.

Fransman, W.;Peelen, S.;Hilhorst, S.;Roeleveld, N.;Heederik, D.;Kromhouts, H. (2007) A pooled analysis to study trends in exposure to antineoplastic drugs among nurses. Annals of Occupational Hygiene, 51(3), 231239.

Fransman, W.;Huizer, D.;Tuerk, J.;Kromhout, H. (2007) Inhalation and dermal exposure to eight antineoplastic drugs in an industrial laundry facility.International Archives of Occupational and Environmental Health, 80(5), 396-403.

Gilbar, P.J. (2005) External contamination of cytotoxic drug vials. Journal of Pharmacy Practice and Research, 35(4), 264-265.

Gilles, L.; Favier, B.;Catillon, F.; Dussart, C.; Peyron, F.;Simoens, X., et al. (2009) Optimisation des procédures de manipulation des chimiothérapies anticancéreuses : impact des contrôles de contamination environnementaux. Bulletin du Cancer, 96(9), 839-849. [French]

Hedmer, M.;Jonsson, B.A.;Nygren, O. (2004) Development and validation of methods for environmental monitoring of cyclophosphamide in workplaces.Journal of Environmental Monitoring, 6(12), 979-984.

Hedmer, M.; Wohlfart, G. (2012) Hygienic guidance values for wipe sampling of antineoplasic drugs in Swedish hospitals.Journal of Environmental Monitoring, 14(7), 1968-1675.

Huizing, M.T.;Rosing, H.;Koopman, F.; Keung, A.C.;Pinedo, H.M.;Beijnen, J.H. (1995) High-performance liquid chromatographic procedures for the quantitative determination of paclitaxel (Taxol) in human urine. Journal of chromatography.B, Biomedical sciences and applications, 664(2), 373-382.

International Agency for Research on Cancer (IARC). (2016) IARC monographs.Ressource document.http://monographs.iarc.fr/ENG/Classification/. Accessed 20 june 2016.

International Society of Oncology Pharmacy Practitioners Standards Committee.(2007) ISOPP standards of practice.Safe handling of cytotoxics.Journal of Oncology Pharmacy Practice, 13,1-81.

Juhascik, M.P.; Jenkins, A.J.(2009) Comparison of Liquid/Liquid and Solid-Phase Extraction for Alkaline Drugs.Journal of Chromatographic Science, 47(7), 553-557.

Kiffmeyer, T.K.;Tuerk, J.; Hahn, M.;Stuetzer, H.;Hadtstein, C.; Heinemann, A., et al. (2013) Application and Assessment of a Regular Environmental Monitoring of the Antineoplastic Drug Contamination Level in Pharmacies - The MEWIP Project. Annals of Occupational Hygiene, 57(4), 444-455. 
Konate, A.;Poupon, J.; Villa, A.;Garnier, R.;Hasni-Pichard, H.;Mezzaroba, D., et al. (2011) Evaluation of environmental contamination by platinum and exposure risks for healthcare workers during a heated intraperitoneal perioperative chemotherapy (HIPEC) procedure. Journal of Surgical Oncology, 103(1), 6-9.

Kopp, B.;Crauste-Manciet, S.;Guibert, A.; Mourier, W.;Guerrault-Moro, M.N.; Ferrari, S., et al. (2013) Environmental and biological monitoring of platinum-containing drugs in two hospital pharmacies using positive air pressure isolators. Annals of Occupational Hygiene, 57(3), 374-383.

Kosjek, T.;Perko, S.;Žigon, D, Heath, E. (2013) Fluorouracil in the environment: analysis, occurrence, degradation and transformation. Journal of Chromatography A, 1290, 62-72.

Krstey, S.;Perunicić, B.;Vidacović, A. (2003) Work practice and some adverse health effects in nurses handling antineoplastic drugs.MedicinadelLavoro, 94(5), 432-439.

Lee, S.G.;Tkaczuk, M.;Jankewicz, G.;Ambados, F. (2007) Surface Contamination from Cytotoxic Chemotherapy Following Preparation and Administration.Journal of Pharmacy Practice and Research, 37(4), 271-276.

Mason, H.J.; Blair, S.;Sams, C.; Jones, K.;Garfitt, S.J.;Cuschieri, M.J., et al. (2005) Exposure to antineoplastic drugs in two UK hospital pharmacy units. Annals of Occupational Hygiene, 49(7), 603-610.

McDevitt, J.J.; Lees, P.S.;McDiarmid, M.A. (1993) Exposure of hospital pharmacists and nurses to antineoplastic agents.Journal of Occupational Medicine, 35(1), 57-60.

McDiarmid, M.A.; Rogers, B.; Oliver, M.S. (2014) Chromosomal effects of non-alkylating drug exposure in oncology personnel.Environmental and Molecular Mutagenesis,55(4), 369-374.

Meijster, T.;Fransman, W.; Veldhof, R.;Kromhout, H. (2006) Exposure to antineoplastic drugs outside the hospital environment.Annals of Occupational Hygiene,50(7), 657-664.

Micoli, G.;Turci, R.;Arpellini, M.;Minoia, C. (2001) Determination of 5-fluorouracil in environmental samples by solid-phase extraction and high-performance liquid chromatography with ultraviolet detection.Journal of chromatography.B, Biomedical sciences and applications, 750(1), 25-32.

Minoia, C.;Turci, R.;Sottani, C.;Schiavi, A.;Perbellini, L.;Angeleri, S., et al.(1998)Application of highperformance liquid-chromatography tandem mass-spectrometry in the environmental and biological monitoring of health-care personnel occupationally exposed to cyclophosphamide and ifosfamide. Rapid Communications in Mass Spectrometry, 12(20), 1485-1493.

Naito, T.; Osawa, T.; Suzuki, N.; Goto, T.; Takada, A.; Nakamichi, H., et al. (2012) Comparison of contamination levels on the exterior surfaces of vials containing platinum anticancer drugs in Japan. Biological and Pharmaceutical Bulletin, 35(11), 2043-2049.

Ng, L.M.; Jaffe, N. (1970) Possible hazards of handling antineoplastic drugs. Pediatrics, 46(4), 648-649.

NIOSH (National Institute for Occupational Safety and Health). (2004) NIOSH Alert: Preventing Occupational Exposures to Antineoplastic and Other Hazardous Drugs in Health Care Settings. No. 2004-165. Atlanta (GA): Department of Health and Human Services (US), Centers for Disease Control and Prevention. Ressource document.www.cdc.gov/niosh/docs/2004-165/. Accessed 20 june 2016.

NIOSH (National Institute for Occupational Safety and Health). (2014) NIOSH list of antineoplastic drugs and other hazardous drugs in healthcare settings. No. 2014-138. Atlanta (GA): Department of Health and Human Services (US), Centers for Disease Control and Prevention. Ressource document.www.cdc.gov/niosh/docs/2014-138/. Accessed 20 june 2016.

Nussbaumer, S.; Fleury-Souverain, S.;Antinori, P.;Sadeghipour, F.;Hochstrasser, D.F.;Bonnabry, P., et al. (2010) Simultaneous quantification of ten cytotoxic drugs by a validated LC-ESI-MS/MS method.Analytical and Bioanalytical Chemistry, 398(7-8), 3033-3042. 
Nussbaumer, S.;Geiser, L.;Sadeghipour, F.;Hochstrasser, D.;Bonnabry, P.;Veuthey, J.L., et al.(2012) Wipe sampling procedure coupled to LC-MS/MS analysis for the simultaneous determination of 10 cytotoxic drugs on different surfaces. Analytical and Bioanalytical Chemistry,402(8), 2499-2509.

Nygren, O.; Gustavsson, B.; Strom, L.; Friberg, A. (2002) Cisplatin contamination observed on the outside of drug vials. Annals of Occupational Hygiene, 46(6), 555-557.

OSHA (Occupational Safety and Health Administration, United States Department of Labor).(1999)Controlling Occupational Exposure to Hazardous Drugs.OSHA Technical Manual, Section VI, Chapter 2.Ressource document. https://www.osha.gov/dts/osta/otm/otm_vi/otm_vi_2.html. Accessed 20 june 2016.

Pethran, A.;Schierl, R.;Hauff, K.; Grimm, C.H.; Boos, K.S.; Nowak, D. (2003) Uptake of antineoplastic agents in pharmacy and hospital personnel. Part I: monitoring of urinary concentrations. International Archives of Occupational and Environmental Health, 76:5-10.

Randolph, S.A. (2012) (NIOSH) Hazardous Drugs in Health Care Settings - Recognition and Control.Workplace Health and Safety, 60(9), 412.

Rombaldi, F.; Cassini, C.; Salvador, M.;Saffi, J.;Erdtmann, B. (2009) Occupational risk assessment of genotoxicity and oxidative stress in workers handling anti-neoplastic drugs during a working week.Mutagenesis, 24(2), 143-148.

Sabatini, L.; Barbieri, A.; Tosi, M.;Violante, F.S. (2005) A new high-performance liquid chromatographic/ electrospray ionization tandem mass spectrometric method for the simultaneous determination of cyclophosphamide, methotrexate and 5-fluorouracil as markers of surface contamination for occupational exposure monitoring. Journal of Mass Spectrometry, 40(5), 669-674.

Schierl, R.;Böhlandt, A.; Nowak, D. (2009) Guidance Values for Surfaces Monitoring of Antineoplasic Drugs in German Pharmacies. Annals of Occupational Hygiene, 53(7), 703-711.

Schierl, R.; Herwig, A.;Pfaller, A.;Groebmair, S.; Fischer, E.(2010) Surface contamination of antineoplastic drug vials: comparison of unprotected and protected vials. American Journal of Health-System Pharmacy, 67(6), 428-429.

Schierl, R.;Masini, C.;Groeneveld, S.; Fischer, E.;Böhlandt, A.;Rosini, V., et al. (2016) Environmental contamination by cyclophosphamide preparation: Comparison of conventional manual production in biological safety cabinet and robot-assisted production by APOTECAchemo. Journal of Oncology Pharmacy Practice, 22(1), 37-45.

Schmaus, G.;Schierl, R.;Funck, S. (2002) Monitoring surface contamination by antineoplastic drugs using gas chromatography-mass spectrometry and voltammetry.American Journal of Health-System Pharmacy,59(10), 956-961.

Schreiber C.; Radon K.;Pethran A.;Schierl R.;Hauff K.; Grimm C.H. (2003) Uptake of antineoplastic agents in pharmacy personnel. Part II study of work-related risk factors.International Archives of Occupational and Environmental Health, 76(1), 11-16.

Sessink, P.J.; Boer, K.A.;Scheefhals, A.P.;Anzion, R.B.;Bos, R.P. (1992) Occupational exposure to antineoplastic agents at several departments in a hospital. Environmental contamination and excretion of cyclophosphamide and ifosfamide in urine of exposed workers.International Archives of Occupational and Environmental Health, 64(2), 105-112.

Sessink, P.J.; Connor, T.H.; Jorgenson, J.A.; Tyler, T.G. (2011) Reduction in surface contamination with antineoplastic drugs in 22 hospital pharmacies in the US following implementation of a closed-system drug transfer device. Journal of Oncology Pharmacy Practice, 17(1), 39-48.

Sessink, P.J.;Leclercq, G.M.;Wouters, D.M.;Halbardier, L.;Hammad, C.;Kassoul, N. (2015) Environmental contamination, product contamination and workers exposure using a robotic system for antineoplastic drug preparation. Journal of Oncology Pharmacy Practice, 21(2), 118-127. 
Siderov, J.;Kirsa, S.;McLauchlan, R. (2010) Reducing workplace cytotoxic surface contamination using a closed-system drug transfer device.Journal of Oncology Pharmacy Practice, 16(1), 19-25.

Smith, J.P.; Sammons, D.L.; Pretty, J.R.; Kurtz, K.S.; Robertson, S.A.;DeBord, D.G., et al. (2016) Detection of 5-fluorouracil surface contamination in near real time. Journal of Oncology Pharmacy Practice, 22(1), 60-67.

Sottani, C.;Turci, R.;Micoli, G.;Fiorentino, M.L.;Minoia, C. (2000) Rapid and sensitive determination of paclitaxel (Taxol) in environmental samples by high- performance liquid chromatography tandem mass spectrometry. Rapid Communications in Mass Spectrometry, 14(10), 930-935.

Sottani, C.;Turci, R.;Schierl, R.;Gaggeri, R.; Barbieri, A.;Violante, F.S., et al. (2007) Simultaneous determination of gemcitabine, taxol, cyclophosphamide and ifosfamide in wipe samples by high-performance liquid chromatography/tandem mass spectrometry: protocol of validation and uncertainty of measurement. Rapid Communications in Mass Spectrometry, 21(7), 1289-1296.

Sottani, C.;Porro, B.;Comelli, M.;Imbriani, M.;Minoia, C. (2010) An analysis to study trends in occupational exposure to antineoplastic drugs among health care workers. Journal of chromatography.B, Biomedical sciences and applications, 878(27), 2593-2605.

Stücker, I.;Mandereau, L.;Hémon, D. (1993) Relationship between birthweight and occupational exposure to cytostatic drugs during or before pregnancy.Scandinavian Journal of Work, Environment \& Health, 19(3), 148-153.

Tkaczuk, M.; Lee, S.G.;Jankewicz, G.;Ambados, F. (2010) Surface contamination of cytotoxic drug 5fluorouracil (5-FU) and decontamination. Journal of Health, Safety and Environment, 26(2), 171-181.

Touzin, K.;Bussières, J.F.;Langlois, E.; Lefebvre, M.; Gallant, C. (2008) Cyclophosphamide contamination observed on the external surfaces of drug vials and the efficacy of cleaning on vial contamination. Annals of Occupational Hygiene, 52(8), 765-771.

Tuerk, J.;Kiffmeyer, T.K.;Hadtstein, C.; Heinemann, A.; Hahn, M.;Stuetzer, M., et al. (2011) Development and validation of an LC-MS/MS procedure for environmental monitoring of eight cytostatic drugs in pharmacies.International Journal of Environmental Analytical Chemistry, 91(12), 1178-1190.

Turci, R.;Micoli,G.;Minoia, C. (2000) Determination of methotrexate in environmental samples by solid phase extraction and high performance liquid chromatography: ultraviolet or tandem mass spectrometry detection? Rapid Communications in Mass Spectrometry, 14(8), 685-691.

Turci, R.;Sottani, C.;Spagnoli, G.;Minoia, C. (2003) Biological and environmental monitoring of hospital personnel exposed to antineoplastic agents: a review of analytical methods. Journal of chromatography.B, Biomedical sciences and applications, 789(2), 169-209.

Turci, R.;Minoia, C. (2006) Residual hazard assessment related to handling of antineoplastic drugs: safety system evolution and quality assurance of analytical measurement. Annals of the New York Academy of Sciences, 1076, 649-656.

USP <797>(2004).Guidebook to pharmaceutical compounding-sterile preparations. In: The United States pharmacopeia [28th rev] - The national formulary [23rd ed] (pp 2461-2477). Rockville (MD): United States Pharmacopeial Convention.

Valanis, B.G.; Vollmer, W.M.;Labuhn, K.T.; Glass, A.G. (1993) Association of antineoplastic drug handling with acute adverse effects in pharmacy personnel.American journal of hospital pharmacy, 50(3), 455-462.

Valanis, B.G.; Vollmer, W.M.; Steele, P. (1999)Occupational exposure to antineoplastic agents: self-reported miscarriages and stillbirths among nurses and pharmacists. Journal of Occupational and Environmental Medicine, 41(8), 632-638.

Wick, C.;Slawson, M.H.; Jorgenson, J.A.; Tyler, L.S. (2003) Using a closed-system protective device to reduce personnel exposure to antineoplastic agents.American Journal of Health-System Pharmacy, 60(22), 23142320 . 
Working Committee on the Safe Handling of Hazardous Drugs.(2008) Prevention guide: safe handling of hazardous drugs. Montréal (QC): Association paritaire pour la santé et la sécurité au travail du secteur des affaires sociales. Ressource document.www.irsst.qc.ca/media/documents/PubIRSST/CG-002.pdf. Accessed 20 june 2016.

World Health Organization, regional office for Europe (2002)Good Practice in Occupational Health Services: A Contribution to Horkplace Health. Ressource document. http://www.euro.who.int/_data/assets/pdf_file/0007/115486/E77650.pdf. Accessed 11 november 2016.

Yuki, M.;Sekine, S.;Takase, K.; Ishida, T.;Sessink, P.J. (2013) Exposure of family members to antineoplastic drugs via excreta of treated patients.Journal of Oncology Pharmacy Practice,19(3), 208-217.

Yuki, M.; Ishida, T.;Sekine, S. (2015) Secondary exposure of family members to cyclophosphamide after chemotherapy of outpatients with cancer: a pilot study. Oncology Nursing Forum,42(6), 665-671. 